\title{
Effects of cessation of supplemental feeding on mineral status of red deer Cervus elaphus and wild boar Sus scrofa in the Netherlands
}

\author{
Geert W. T. A. GROOT BRUINDERINK, Dennis R. LAMMERTSMA \\ and Ed HAZEBROEK
}

\begin{abstract}
Groot Bruinderink G. W. T. A., Lammertsma D. R. and Hazebroek E. 2000. Effects of cessation of supplemental feeding on mineral status of red deer Cervus elaphus and wild boar Sus scrofa in the Netherlands. Acta Theriologica 45: 71-85.

From 1987 till 1997 we studied effects of cessation of supplementary feeding on performance of red deer Cervus elaphus Linnaeus, 1758 and wild boar Sus scrofa scrofa Linnaeus, 1758 in the Netherlands. We observed no changes in antler morphology, growth rate and body weight. Recruitment of red deer was unaffected and wild boar recruitment was determined by mast availability. The animals realised adequate dietary protein, energy (except for wild boar in poor mast winters), potassium, magnesium, copper, zinc, iron, and manganese levels from the natural diet. The natural diet of juveniles from both species was short in calcium, phosphorus, and sodium; adult red deer realised insufficient sodium intake. In red deer, bone calcium, phosphorus and total mineralisation declined. Potassium concentration in antlers, red deer and wild boar bone increased by a factor 2,29 , and 36 respectively. In both species bone sodium increased by a factor 2. Concentrations of liver and kidney copper, iron and zinc were unaffected. Our findings suggest that red deer from this study, as a consequence of poor mineral availability, are in calcium and phosphorus stress, while both red deer and wild boar are in sodium stress. Future deficiencies may not be excluded.
\end{abstract}

Key words: Cervus elaphus, Sus scrofa, mineral requirements

Alterra Green World Research, P.O. Box 47, NL-6700 AA Wageningen, The Netherlands; e-mail: g.w.t.a.grootbruinderink@Alterra.dlo.nl

\section{Introduction}

Over the past centuries in the Netherlands and other parts of Europe wild boar Sus scrofa scrofa Linnaeus, 1758 and red deer Cervus elaphus Linnaeus, 1758 were restricted to areas where their presence conflicted least with agriculture. Generally these areas were poor ungulate habitat and a supplementary feeding regime (artificial mineral licks, maize, etc) was considered necessary to allow annual hunting bags. In the Netherlands red deer and wild boar were confined to the Veluwe ( $\left.37^{\circ} 9^{\prime} \mathrm{N}, 6^{\circ} 26^{\prime} \mathrm{W}\right)$ : 80,000 ha of forests, heathlands and sanddrifts. Because of poor nutrient availability and vegetation diversity, inherent to the dry, acid, sandy substrate, this area is considered a poor ungulate habitat (Bokdam and Wallis de Vries 1992). Over the past 50 years the pioneer association of Scots-pine 
with lichen (Cladonio-Pinetum sylvestris), and the area of heather (Calluna vulgaris, Erica tetralix) is rapidly being replaced by wavy hairgrass (Deschampsia flexuosa), bilberry (Vaccinium myrtillus) and cowberry (V. vitis-idaea) (Groot Bruinderink and Hazebroek 1995). In response to this increase in the natural food supply, the question has recently been raised as to whether the wild ungulates could now satisfactorily maintain themselves without the traditional food supplementation. We monitored the performance of two populations of red deer and wild boar in the Veluwe, following a substantial reduction in numbers and cessation of supplementary feeding, from 1987 until 1997. We used antler growth, body weight, recruitment and mineral status as condition indicators. We assessed digestibility, protein and mineral contents of the natural diet for both species in each season. We calculated nutrient balances on an annual basis for adult and juvenile animals, using dietary standards, corrected for weight and growth rate of the wild ungulates.

\section{Material and methods}

From 1987 till 1997 we studied diet and condition of red deer and wild boar in two forest blocks in the Veluwe, after cessation of supplemental feeding.

Area Hoog-Soeren (HS). This area, part of the Royal Forest Reserve 'Het Loo', is fenced from the rest of the Veluwe area and consists of 1250 ha of heathland ( $450 \mathrm{ha}$ ) and forests. In 1986 numbers of red deer and wild boar were haphazardly reduced and supplementary feeding was stopped. Since then densities were pursued of 5 red deer, 3 wild boar and 6 roe deer per 100 ha.

Area Ugchelen/Hoenderloo (UH). This area, adjacent to the HS area, is managed by the National Forest Service (Staatsbosbeheer). The heathland:forest ratio is practically the same as given for the previous area, but here twelve well kept game meadows offer food of good quality throughout the year. Supplementary feeding stopped in April 1989 and densities of red deer and wild boar were reduced from 4 to $1.5 / 100$ ha and 3 to $2 / 100$ ha, respectively.

Diet composition of each species was assessed per area and season in percentage volume per forage type, using rumen/stomach contents of culled animals (Groot Bruinderink et al. 1994). On the basis of this known dietary profile, we distinguished five phenological seasons as 1: 16 April - 31 July, 2: 1 August - 30 September, 3: 1-31 October, 4: 1 November - 31 December, 5: 1 January - 15 April. In the midst of each season after cessation, we sampled the main forage types in both areas for nutrient analyses, sampling each plant species for the parts that would be selected by deer or boar. For each forage type we assessed the area weighted means for specific gravity (s.g.; g/cc), dry matter contents (\%DM) by drying for 120 hours at $70^{\circ} \mathrm{C}, \mathrm{N}_{\mathrm{Kj}}$ (procedures in NEN 1964), $\mathrm{Zn}, \mathrm{Fe}$ (NEN 1986), Cu, Mg, $\mathrm{Na}, \mathrm{Ca}, \mathrm{K}$, and P (NEN 1981). Mineral contents of animal foods, taken by boar, were derived from CVB (1991) and Ma et al. (1992). Crude protein (CP) was calculated as $\mathrm{N}_{\mathrm{Kj}} \times 6.25$. Data on apparent organic matter digestibility (\%DOM) of the main forage types were obtained by a parallel study (Van Wieren 1996). In assessment of the nutritional quality of any actual diet taken by deer or boar, percentage volume analyses were converted into dry matter percentages, using specific gravity and \%DM per food item. Although mineral content of forages may affect spatial distribution and carrying capacity for large grazing animals (Belovsky and Jordan 1981, McNaughton 1990), in many generalist herbivores, the presumed goal of foraging and patch-selection strategy is nutrient maximisation with energy as the main currency. We therefore considered mineral uptake as subordinate to the animals' effort to meet its energy demands.

Procedures to assess nutrient balances followed step 1-5:

1. Calculation of nutrient content of diets. We calculated mineral,"DOM and CP contents of the diet for the two ungulate species per season: 


$$
[\mathrm{i}]_{\text {diet }}=\sum_{\mathrm{j}=1}^{n}\left(\% \mathrm{DM}_{\mathrm{j}} \times[\mathrm{i}]_{\mathrm{j}}\right) / \sum_{\mathrm{j}=1}^{n} \% \mathrm{DM}_{\mathrm{j}}
$$

in which [i] $]_{\text {diet }}$ is the concentration of nutrient ' $\mathrm{i}$ ', \%DOM or \%CP of the diet, $n$ is the number of forage types in the diet, $\% \mathrm{DM}_{\mathrm{j}}$ is \%DM of forage type ' $\mathrm{j}$ ', and [i $]_{\mathrm{j}}$ is the concentration of nutrient ' $\mathrm{i}$ ', \%DOM or $\% \mathrm{CP}$ in forage type ' $\mathrm{j}$ '.

2. Calculation of energy content of actual diet. For ruminants we derived metabolic energy (ME in $\mathrm{MJ} / \mathrm{kg} \mathrm{DM}$ ) per forage type from DOM data and digestible crude protein (DCP $=57.5 \% \mathrm{~N}_{\mathrm{Kj}}-38.7 \mathrm{~g} / \mathrm{kg}$ DM; Van Soest 1982). For DOM/DCP values > 7, ME $=0.01506$ DOM (Van Es 1978). Annual weighted mean values for DOM/DCP for red deer diets was 8.3. For wild boar we used the regression for domestic pigs (CVB 1991): $\mathrm{ME}=0.0182 \mathrm{DOM}$.

3. Calculation of daily energy requirements and dry matter intake needed to meet these requirements. We used data on liveweights and growth of caught and culled animals in order to calculate daily energy requirements (ME in $\mathrm{MJ} /$ day) for red deer and wild boar. Energy requirements for red deer, converting data from Fennessy et al. (1981) to our calendar, were $0.82,0.77,0.68,0.66$, and $0.69 \mathrm{MJ} / \mathrm{kg}$ $\mathrm{BM}^{0.75} /$ day, for seasons $1-5$ respectively.

In wild boar optimal growth is limited to rich mast years (Groot Bruinderink et al. 1994). For adult maintenance requirements we followed ARC (1981) procedures for domestic pigs: $0.528 \times \mathrm{BM}^{0.75}$ $\mathrm{MJ} /$ day. Requirements for growth are $1.8 \mathrm{MJ} / 100 \mathrm{~g}$ growth. By combining calculated daily energy requirements with calculated energy contents of the diet, we calculated daily dry matter intake DI, needed to meet these requirements.

4. Calculation of mineral requirements. Since males of both species grow heaviest, we restricted calculations for adult mineral requirements to males only. We based calculations for red deer on the factorial approach for beef cattle (Ca, P - NRC 1988a; Mg, Na, K - ARC 1972). For wild boar we used the factorial approach for domestic pigs (Ca, Mg, Na - ARC 1981; P - ARC 1981; Jongbloed 1987; K INRA 1984; Jongbloed 1987). Weighted mean liveweight BM for an adult red deer stag (season 1-5) was $133 \mathrm{~kg}$, for a weaned calf (season 3-5) $57 \mathrm{~kg}$ and its mean LWG (season 3-5) $56 \mathrm{~g} / \mathrm{d}$. The regressions are (all requirements in $\mathrm{g} / \mathrm{d}$; a.c. - absorption coefficient):

Ca: adult $0.0154 \mathrm{BM}$; a.c. 0.38 ; calf $8+0.0367 \mathrm{BM}+0.00848 \mathrm{LWG}$; antler growth: $2.8 \mathrm{~g} / \mathrm{d}$ (Muir et al. 1987);

P: adult $0.0143 \mathrm{BM}$; a.c. 0.5 ; calf $0.884+0.05 \mathrm{BM}+0.00486 \mathrm{LWG}$;

$\mathrm{Mg}$ : adult $0.003 \mathrm{BM}$; a.c. 0.20 ; calf $0.003 \mathrm{BM}+0.003 \mathrm{LWG}$;

$\mathrm{Na}$ a adult $0.017 \mathrm{BM}$; a.c. 1.0 ; calf $0.017 \mathrm{BM}+0.014 \mathrm{LWG}$

$\mathrm{K}$ : adult $0.08 \mathrm{BM}$; a.c. 1.0 ; calf $0.08 \mathrm{BM}+0.0016 \mathrm{LWG}$.

The weighted mean BM of an adult male wild boar in rich mast years (season 1-5) was $65 \mathrm{~kg}$, for a weaned piglet (season 3-5) $38 \mathrm{~kg}$ and its growth rate LWG (season 3-5): $97 \mathrm{~g} / \mathrm{d}$. In poor years these figures were 56 and $20 \mathrm{~kg}$ and $26.3 \mathrm{~g} / \mathrm{d}$.

Regressions are:

$$
\begin{gathered}
\text { Ca: } 0.033 \mathrm{BM}+\mathrm{LWG} / 1000 \times(12.5-0.1 \mathrm{BM}) ; \text { a.c. for juveniles } 0.60 \text {, for adults } 0.51 \text {; } \\
\text { P: } 0.03 \mathrm{BM}+\mathrm{LWG} / 1000 \times(10.0-0.1 \mathrm{BM}) ; \text { a.c. } 0.33 ; \\
\mathrm{Mg}: 0.0008 \mathrm{BM}+0.0008 \mathrm{LWG} \text { a.c. } 0.3 ; \\
\mathrm{Na}: 0.00114 \mathrm{BM}+.0013 \mathrm{LWG} \text {; a.c. } 0.9 ; \\
\text { K: } 0.02+0.0028 \mathrm{LWG} \text {; a.c. } 0.45 .
\end{gathered}
$$

5. Final estimation of nutrient balance. We considered nutrient requirements of juveniles during lactation (season 1 and 2) to be met by the mothers' milk; juveniles of all species were considered to be weaned from October (season 3). We calculated mean values per nutrient, weighted for all seasons for adults and for season 3-5 for weaned juveniles. We calculated balances of nutrient 'i' as step 3 minus step 4: [realised daily intake $]_{\mathrm{i}}$ - [required daily intake $]_{\mathrm{i}}$

Since no regressions were available for a factorial approach for copper, zinc, iron, and manganese requirements, we compared dietary concentrations with standards for livestock forages, although these standards are probably too high (Little 1980, Bokdam and Wallis de Vries 1992). Again we used mean values per nutrient, weighted for all seasons for adults and for season 3-5 for weaned juveniles. We used ARC (1972) and NRC (1988á) cattle standards for forage quality for red deer and ARC (1981) and NRC (1988b) standards for domestic pig food quality for wild boar. 
We assessed dry weights of the stomach contents of wild boar during late winter (January-April) in rich and poor mast years, as an indicator for ingestion.

\section{Condition indicators: body weight, antler morphology, recruitment and mineral status}

Changes in body weight, if corrected for sex, age, and season, are a sensitive reflection of the species' capacity to maintain condition, responding directly to changes in forage availability and quality (Putman et al. 1996).

If corrected for the stags' age, antler weight can be used as a condition indicator of the herd (Hyvärinen et al. 1977, Lincoln 1992). We measured the coronet perimeter and length of the main beam $(\mathrm{cm})$, and recorded the total number of points and the 'air'-dry weight $(\mathrm{g})$ of cast antlers. Volume (cc) was measured by water displacement in order to assess specific gravity $(\mathrm{g} / \mathrm{cc})$.

Resource limitation may result in a reduction in fertility or delayed age of puberty in red deer (Putman et al. 1996) and wild boar (Pepin and Mauget 1989). We defined recruitment as the average number of piglets older than 2 months per adult sow or the number of calves per hind during autumn and winter. Data on recruitment were obtained by night and day observations from 1988 to 1992 and additional data from an annual spring census conducted by local management in April. Uterine contents of a limited number of animals were also recorded.

$\mathrm{Ca}, \mathrm{Mg}, \mathrm{P}, \mathrm{Zn}, \mathrm{Cu}, \mathrm{Fe}, \mathrm{K}$ and $\mathrm{Na}$ contents of bone and antler reflect their status in the animal (Black 1960, Hyvärinen et al. 1977, NRC 1980), and in particular floating ribs are sensitive to changes in $\mathrm{Ca}$ and $\mathrm{P}$ status (Langlands 1987). For monitoring $\mathrm{Fe}, \mathrm{Cu}$ and $\mathrm{Zn}$ status the liver can be used, and the kidney cortex may provide reliable information on $\mathrm{Cu}$ and $\mathrm{Zn}$ status (NRC 1980, Robbins 1983; McDowell et al. 1984, Langlands 1987, Hyvärinen and Nygrén 1993).

From 1987 to 1997, following cessation of supplementary feeding, we recorded in both study areas, the body weight of red deer and wild boar, culled during the winter half-year (season $3-5$ ), and sampled floating ribs, liver and kidneys. Body weights and antler morphology could be compared with those of animals from the period immediately prior to this, while they were still receiving supplementary rations (Table 1 ).

Area, diet, season, age, sex and location on the organ, may interact in the mineral contents of antler, bone, liver and kidney (Robbins 1983, Hyvärinen and Nygrén 1993). We standardised sampling of the main lobe of the liver and analysed the whole kidney cortex. In antlers, $3 \mathrm{~cm}$ deep cores were drilled at the top, the middle, and the base of a haphazard subsample from all coronet-classes. We used an $8 \mathrm{~mm}$ titanium drill, a titanium knife and, for fragmentation of ribs, a plastic hammer to avoid

Table 1. Sample size of the analysis of the effect of cessation of supplemental feeding on condition of red deer and wild boar. HS - area Hoog-Soeren, UH - area Ugchelen/Hoenderloo, juveniles - $\leq 12$ months old, adults - > 12 month old, "+" and "-" - period before and after cessation of supplemental feeding, $\mathrm{x}-$ not applicable.

\begin{tabular}{|c|c|c|c|c|c|c|c|c|c|}
\hline \multirow{2}{*}{ Area } & \multirow{2}{*}{ Period } & \multirow{2}{*}{ Species } & \multicolumn{2}{|c|}{ Weight } & \multirow{2}{*}{$\begin{array}{l}\text { Morphology } \\
\text { antler }\end{array}$} & \multicolumn{4}{|c|}{ Mineral status } \\
\hline & & & $\mathrm{MM}: \mathrm{FF}$ & juv : ad & & Rib bone & Liver & Kidney & Antler \\
\hline HS & + & Red deer & $14: 27$ & $13: 28$ & 38 & $\mathrm{x}$ & $\mathrm{x}$ & $\mathrm{x}$ & 7 \\
\hline HS & - & Red deer & 68: 99 & $85: 82$ & 107 & 53 & 89 & 88 & 57 \\
\hline HS & + & Wild boar & $6: 16$ & $9: 33$ & $\mathrm{x}$ & $\mathrm{x}$ & $\mathrm{x}$ & $\mathrm{x}$ & $\mathrm{x}$ \\
\hline HS & - & Wild boar & $212: 218$ & $158: 273$ & $\mathrm{x}$ & 63 & 128 & 122 & $\mathrm{x}$ \\
\hline UH & + & Red deer & $32: 39$ & $31: 42$ & 26 & $\mathrm{x}$ & $\mathrm{x}$ & $\mathrm{x}$ & 23 \\
\hline UH & - & Red deer & $81: 76$ & $76: 81$ & 44 & 52 & 90 & 116 & 50 \\
\hline UH & + & Wild boar & $27: 47$ & $27: 47$ & $\mathrm{x}$ & $\mathrm{x}$ & $\mathrm{x}$ & $\mathrm{x}$ & $\mathrm{x}$ \\
\hline UH & - & Wild boar & $116: 171$ & $174: 113$ & $\mathrm{x}$ & 102 & 223 & 226 & $\mathrm{x}$ \\
\hline
\end{tabular}


traces of equipment contaminating the samples. Antler and bone samples were milled, dried at $105^{\circ} \mathrm{C}$ and dissolved in $4 \mathrm{ml} \mathrm{HNO}{ }_{3} 65 \%$ suprapur Merck (ref. sample Bone meal NIST 1486). P was assessed using an autoanalyser and molybdenum colouring (Skalar). $\mathrm{Zn}, \mathrm{Cu}, \mathrm{Fe}, \mathrm{Mg}, \mathrm{Ca}, \mathrm{Na}$ and $\mathrm{K}$ were determined by flame-AAS (IL video 12 ). Liver and kidney $\mathrm{Cu}, \mathrm{Fe}$, and $\mathrm{Zn}$ followed the same procedures (ref. sample pig kidney CRM 186) after dry freezing for 2 hours. Bone ash, indicative for the degree of mineralisation (Wallis de Vries 1994), was determined by $850^{\circ} \mathrm{C}$ for 2 hours. We calculated the correlation between bone ash $(\mathrm{y})$ and $\Sigma([\mathrm{Ca}],[\mathrm{P}],[\mathrm{Cu}],[\mathrm{Fe}],[\mathrm{Na}],[\mathrm{K}],[\mathrm{Zn}],[\mathrm{Mg}])(\mathrm{x})$ as y $=9.043+(2.059$ $\times \mathrm{x}) ; R^{2}=0.70 ; n=93$.

Total investment of mineral ' $i$ ' in antlers was calculated as: antler weight $\times[i]_{\text {antler. }}$.

\section{Statistics}

Effects of season, age and mast availability on dry weight of stomach contents of wild boar were studied using the regression screening technique (McCullagh and Nelder 1989). Data on body weight, antler morphology and mineral concentrations in antlers, floating rib, liver and kidney were log-transformed and analysed by a linear mixed model (using residual maximum likelihood, or REML) with year-area group and animal as random factors and data coded for:

- agesex: juveniles ( $\leq 12$ months), adult males and adult females;

- area (HS and UH);

- years-after-cessation of supplementary feeding

- mast availability. A binary distinction was made between rich and poor mast years, depending on beech-mast availability in season 5 (Groot Bruinderink et al. 1994).

In the case of analysis of antlers, data were further coded to discern the location on the antler (loc) and three age groups in stags: juvenile (coronet $\leq 21 \mathrm{~cm}$ perimeter), middle class $(21<\mathrm{cm}$ perimeter $\leq 25 \mathrm{~cm}$ ) and older (perimeter $>25 \mathrm{~cm}$ ). Model predictions are presented (means $\pm \mathrm{SE}$ ). For the analysis we used the statistical package GENSTAT (GENSTAT 5 Committee 1993). Effects of cessation of supplementary feeding on recruitment, could not be analysed statistically, since we lacked the necessary data from the period before cessation.

\section{Results}

Results of our study of the botanical composition of the diets of red deer and wild boar were published elsewhere (Groot Bruinderink et al. 1994, Groot Bruinderink and Hazebroek 1995). Interspecific differences in dietary quality were the logical outcome of differences in foraging strategy, seasonal variation in dry matter contents, specific gravity, and nutrient contents of the main forage types. Protein contents of all diets peaked in summer, and the lowest values were found in the red

Table 2. Crude protein CP (\%DM) and energy ME (MJ/kg DM) contents of the diet of red deer and wild boar (in rich + and poor - mast years) per season, in the Veluwe, the Netherlands. Season 1: 16 April 31 July; 2: 1 August - 30 September; 3: 1 -31 October; 4: 1 November - 31 December; $5: 1$ January 15 April.

\begin{tabular}{|c|c|c|c|c|c|c|c|c|c|c|}
\hline & $\mathrm{CP}$ & $\mathrm{ME}$ & $\mathrm{CP}$ & $\mathrm{ME}$ & $\mathrm{CP}$ & ME & $\mathrm{CP}$ & $\mathrm{ME}$ & $\mathrm{CP}$ & $\mathrm{ME}$ \\
\hline Season & \multicolumn{2}{|c|}{1} & \multicolumn{2}{|c|}{2} & \multicolumn{2}{|c|}{3} & \multicolumn{2}{|c|}{4} & \multicolumn{2}{|c|}{5} \\
\hline Red deer & 15 & 10 & 13 & 9 & 11 & 8 & 9 & 7 & 10 & 7 \\
\hline Wild boar + & 16 & 8 & 12 & 12 & 12 & 13 & 12 & 11 & 12 & 9 \\
\hline Wld boar - & 16 & 8 & 12 & 12 & 11 & 13 & 13 & 8 & 12 & 7 \\
\hline
\end{tabular}


Table 3. Mineral composition of the diet of red deer and wild boar (in rich + and poor - mast years) in the Veluwe. $\mathrm{Ca}, \mathrm{P}, \mathrm{Na}, \mathrm{K}, \mathrm{Mg}, \mathrm{Cu}, \mathrm{Zn}$, and $\mathrm{Fe}$ in $\mathrm{mg} / \mathrm{kg} \mathrm{DM}$. Means are area weighted means for season 1-5 in adults and season 3-5 in juveniles after weaning (seasons 1-5 for explanations see Table 2).

\begin{tabular}{|c|c|c|c|c|c|c|c|c|c|}
\hline & $\mathrm{Ca}$ & $\mathrm{P}$ & $\mathrm{Ca}: \mathrm{P}$ & $\mathrm{Na}$ & $\mathrm{K}$ & $\mathrm{Mg}$ & $\mathrm{Cu}$ & $\mathrm{Zn}$ & $\mathrm{Fe}$ \\
\hline \multicolumn{10}{|c|}{ Red deer } \\
\hline Mean juv & 3822 & 1374 & 2.7 & 332 & 9068 & 1370 & 10.0 & 48.6 & 103 \\
\hline Mean adult & 4053 & 1569 & 2.6 & 315 & 11353 & 1520 & 10.8 & 46.7 & 91 \\
\hline \multicolumn{10}{|c|}{ Wild boar + } \\
\hline Mean juv & 3357 & 1670 & 2.0 & 396 & 8199 & 1141 & 19.8 & 134.8 & 210 \\
\hline Mean adult & 3667 & 1843 & 2.1 & 548 & 10615 & 1271 & 17.6 & 96.4 & 196 \\
\hline \multicolumn{10}{|c|}{ Wild boar - } \\
\hline Mean juv & 2774 & 2361 & 1.2 & 720 & 13029 & 1288 & 14.6 & 163.0 & 381 \\
\hline Mean adult & 3150 & 2239 & 1.5 & 746 & 13530 & 1357 & 14.8 & 113.0 & 304 \\
\hline
\end{tabular}

deer diet during winter (Table 2). Irrespective of mast availability, levels in the wild boar diet never dropped beneath $11 \%$. The energy content of the red deer diet peaked during summer/early autumn, and that of wild boar during late autumn/ /early winter. The wild boar diet was relatively poor in energy during summer and, in particular, in late winter of a poor mast year (Table 2).

The red deer diet was relatively poor in $\mathrm{P}$ and $\mathrm{Na}$ (Table 3 ). For red deer, mean dietary $\mathrm{Na}$ concentrations realised during the growing season (1-3) and the winter period (4-5) were 288 and $348 \mathrm{mg} / \mathrm{kg}$. K contents were 14,148 and $8053 \mathrm{mg} / \mathrm{kg}$, respectively. For wild boar mean dietary $\mathrm{Na}$ contents in the growing season of a rich and a poor mast year were 703 and $725 \mathrm{mg} / \mathrm{kg}$. K concentrations were 12,645 and $13,348 \mathrm{mg} / \mathrm{kg}$. During winter of a rich and a poor mast year, Na levels were 365 and $771 \mathrm{mg} / \mathrm{kg}$; K levels reached 8218 and $13,745 \mathrm{mg} / \mathrm{kg}$.

As compared to red deer, wild boar realised relatively high dietary $\mathrm{Cu}, \mathrm{Zn}$ and $\mathrm{Fe}$ levels.

We calculated energy requirements DE and the corresponding daily intake DI; we estimated nutrient requirements for adult and juvenile red deer and wild boar, based on the factorial approach and calculated balances (Tables 4, 5, 6). Our calculations suggest that all young animals were in negative $\mathrm{Ca}$ and $\mathrm{P}$ balance, as were adult wild boar for $\mathrm{P}$. Red deer were in negative $\mathrm{Na}$ balance, but calculated $\mathrm{Mg}$ and $\mathrm{K}$ balances were positive for both species.

Requirements of $\mathrm{Cu}, \mathrm{Zn}$, and $\mathrm{Fe}$ for the two wild ungulate species, based on livestock standards, compared favourably with concentrations in the diet (Table 7).

Dry weights of the stomach contents of wild boar from January till April (season 5 ) were not affected by mast availability. For adults in rich and poor years these weights were $756( \pm 423)$ and $785( \pm 326) \mathrm{g}$; for juveniles these figures were 412 $( \pm 346)$ and $400( \pm 205) \mathrm{g}$. 
Table 4. Energy requirements ME (in MJ/d) and estimated daily intake DI, needed to meet these requirements (in $\mathrm{kg} \mathrm{DM} / \mathrm{d}$ ), per season, for juvenile (after weaning) and adult red deer and wild boar (rich and poor mast years). Seasons 1-5 for explanation see Table 2, $\mathrm{x}$ - not applicable.

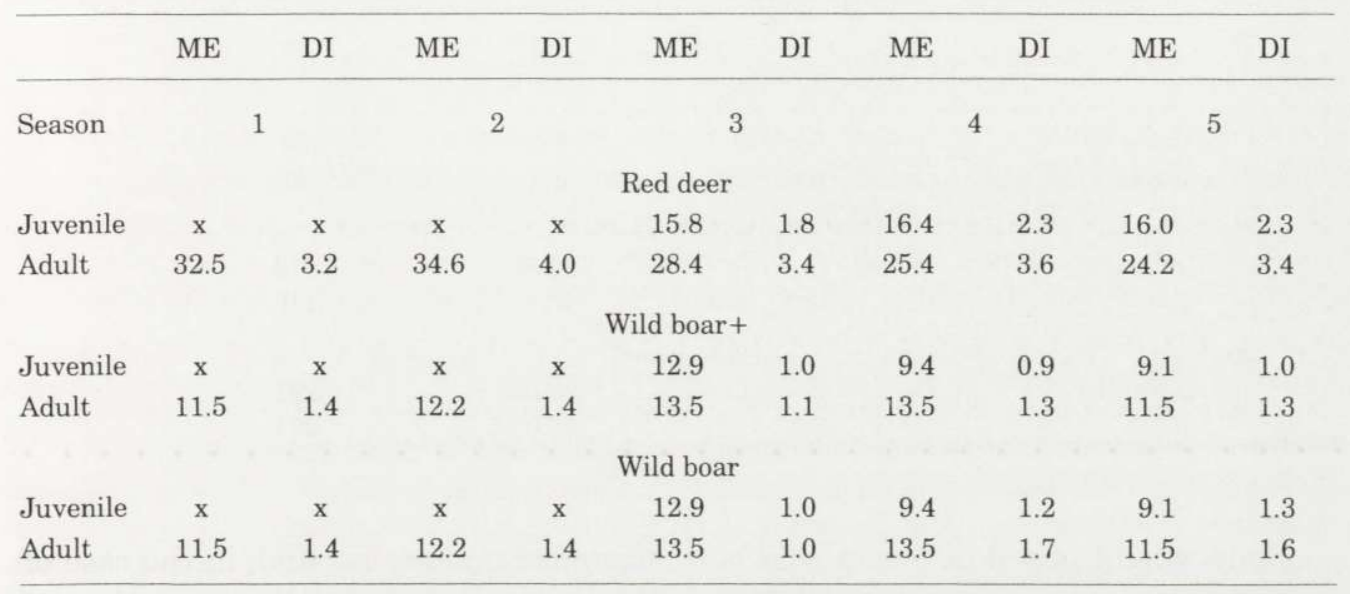

Table 5. Estimated nutrient requirements for juvenile and adult red deer and wild boar $(\mathrm{g} / \mathrm{d})$, based on the factorial approach.

\begin{tabular}{|c|c|c|c|c|c|}
\hline & $\mathrm{Ca}$ & $\mathrm{P}$ & $\mathrm{Na}$ & K & $\mathrm{Mg}$ \\
\hline \multicolumn{6}{|c|}{ Red deer } \\
\hline Juvenile & 10.6 & 4 & 1.8 & 4.6 & 1.7 \\
\hline Adult & 8.1 & 3.8 & 2.3 & 10.6 & 2 \\
\hline \multicolumn{6}{|c|}{ Wild boar } \\
\hline Juvenile & 3.5 & 5.6 & 0.2 & 0.07 & 0.2 \\
\hline Adult & 4.4 & 6.6 & 0.08 & 0.04 & 0.4 \\
\hline
\end{tabular}

Table 6. Nutrient balances (realized - required) in $\mathrm{g} / \mathrm{d}$ for adult and juvenile red deer and wild boar (rich mast years).

\begin{tabular}{lrrrrr}
\hline & $\mathrm{Ca}$ & $\mathrm{P}$ & $\mathrm{Na}$ & $\mathrm{K}$ & $\mathrm{Mg}$ \\
\hline \multicolumn{7}{c}{ Red deer } \\
Juvenile & -2.19 & -0.98 & -1.02 & 15.35 & 1.31 \\
Adult & 4.30 & 1.69 & -1.20 & 29.14 & 3.32 \\
& \multicolumn{7}{c}{ Wild boar } \\
Juvenile & -0.14 & -3.93 & 0.20 & 8.13 & 0.78 \\
Adult & 0.37 & -4.20 & 0.63 & 13.56 & 1.48 \\
\hline
\end{tabular}


Table 7. $[\mathrm{Cu}, \mathrm{Zn}, \mathrm{Fe}]_{\text {diet }}-[\mathrm{Cu}, \mathrm{Zn}, \mathrm{Fe}]_{\text {standard }}(\mathrm{mg} / \mathrm{kg}$ dry $)$ for juvenile and adult red deer and wild boar (rich + and poor - mast years), based on livestock standards.

\begin{tabular}{lcccc}
\hline & $\mathrm{Cu}$ & $\mathrm{Zn}$ & $\mathrm{Fe}$ \\
\hline & \multicolumn{2}{c}{ Red deer } & & \\
Juvenile & 0.0 & & 8.6 & 53 \\
Adult & 0.8 & & 6.7 & 41 \\
& & Wild boar + & \\
Juvenile & 13.8 & & 34.8 & 110 \\
Adult & 12.6 & & 46.4 & 116 \\
& & Wild boar - & \\
Juvenile & 8.6 & & 63.0 & 281 \\
Adult & 9.8 & & 63.0 & 224 \\
\hline
\end{tabular}

Body weight of red deer and wild boar depended on age, sex and, in the case of wild boar, area and mast availability, but was not affected by cessation of supplementary feeding. The initial predicted mean body weight of red deer was 53 $\mathrm{kg}$; after cessation body weight ranged between 47 and $78 \mathrm{~kg}$. Initial wild boar body weight averaged $26 \mathrm{~kg}$; after cessation it ranged between 24 and $33 \mathrm{~kg}$. Antler morphology, weight and specific gravity differed significantly between the years, but were also unaffected by cessation of supplementary feeding. The initial predicted mean number of tines was 7.4 and varied, after cessation, from 6.1 to 8.1. Initial antler length was $82 \mathrm{~cm}$ and varied after cessation from 77 to $92 \mathrm{~cm}$. Initial antler weight was $1867 \mathrm{~g}$ and later varied from 1375 to $2336 \mathrm{~g}$; initial specific gravity was $1.20 \mathrm{~g} / \mathrm{cc}$ and later varied from 1.12 to $1.31 \mathrm{~g} / \mathrm{cc}$.

Between 1987 and 1997, uteri of 17 female calves from the HS forest block did not contain foetuses; uteri of 17 yearling and 18 older hinds all contained foetuses of in average $837( \pm 140)$ and $3382( \pm 973) \mathrm{g}$. In the UH forestry, from 1981-1989 the number of calves per adult hind at the spring census averaged $0.64( \pm 0.04)$; from 1990-1997, $0.73( \pm 0.03)$.

Following the cessation of artificial feeding, recruitment of wild boar in the HS area showed a distinct mast dependency: after a rich and poor mast winter, the average recruitment was $2.5( \pm 0.6)$ and 0.0 piglets per adult sow. The Veluwe mean for supplementary fed animals was in order $2.3( \pm 0.1)$ and $2.1( \pm 0.2)$. In the $\mathrm{UH}$ forestry area, game meadows offered some substitute as forage when mast failed, and recruitment was less affected by cessation of supplementary feeding: 2.2 $( \pm 0.3)$ piglets per adult sow after rich and $1.5( \pm 0.0)$ after poor winters.

\section{Mineral status}

Red deer

Antler K stabilised at $800 \mathrm{mg} / \mathrm{kg} 10$ years after cessation of supplemental feeding and an initial $415 \mathrm{mg} / \mathrm{kg}$; antler $\mathrm{Na}$ was unaffected and the K:Na ratio 

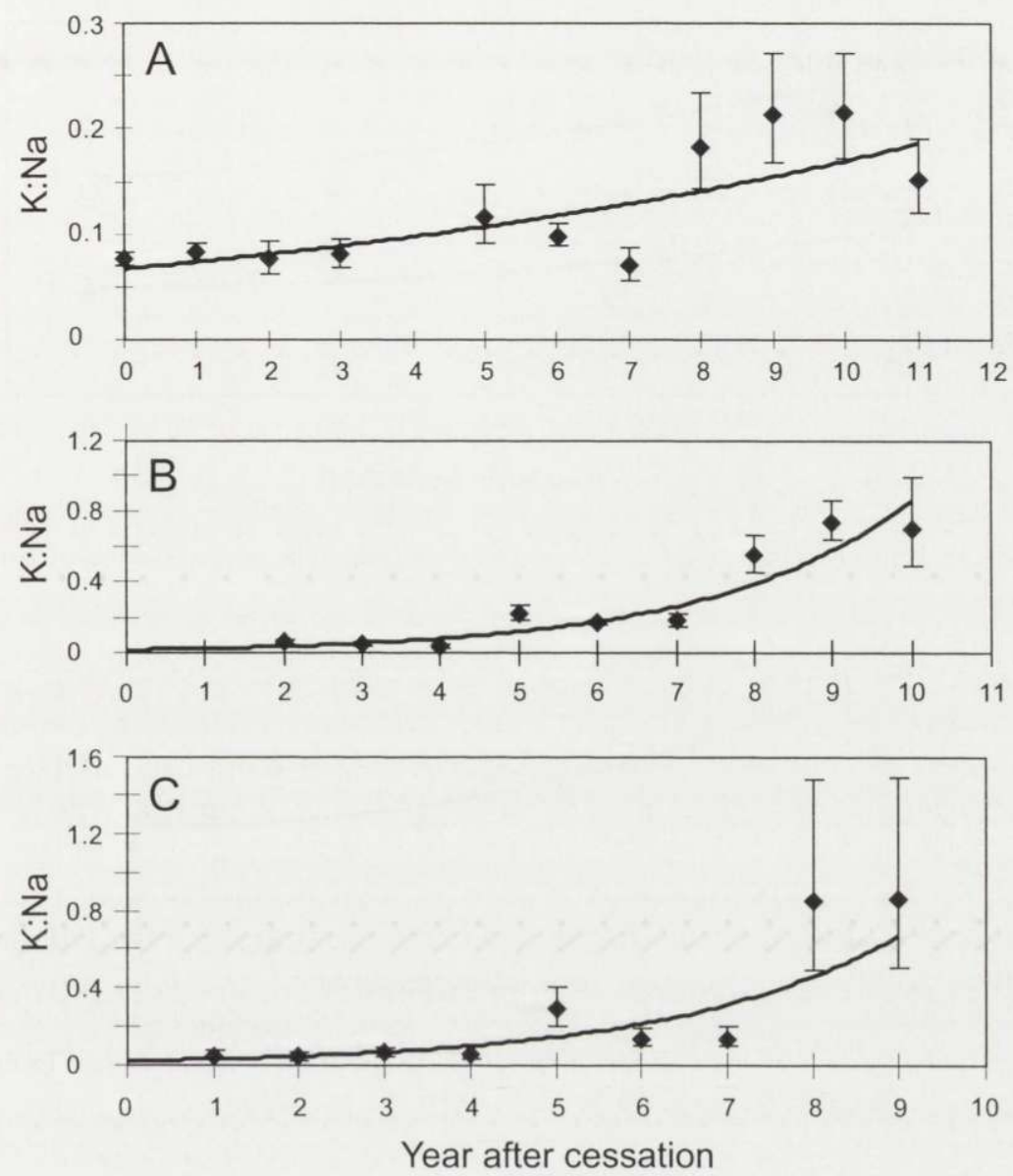

Fig. 1. K:Na ratio $( \pm \mathrm{SE})$ in red deer antlers $\mathrm{A}$, red deer bone $\mathrm{B}$, and wild boar bone $\mathrm{C}$, following cessation of supplemental feeding; data are model predictions.

increased by a factor $2.5(p<0.001)$ (Fig. 1A). Despite a decrease $(p<0.001)$ in antler $\mathrm{Zn}$ from 98 ( 1.0) to a stable 77 (1.1) $\mathrm{mg} / \mathrm{kg}$, antler ash was a stable $600 \mathrm{~g} / \mathrm{kg}$. Total investment of $\mathrm{Fe}, \mathrm{K}, \mathrm{Mg}, \mathrm{Ca}, \mathrm{Na}$ and $\mathrm{P}$ in antler material was unaffected by cessation of supplemental feeding, but $\mathrm{Zn}$ investment decreased $(p<0.001)$ from an initial $200( \pm 1.1)$ to $120( \pm 1.3) \mathrm{mg} 10$ years after cessation.

From an initial level of 175 , bone K increased to a stable $5000 \mathrm{mg} / \mathrm{kg}(p<0.001)$. Bone Na stabilised $(p<0.001)$ from an initial 2986 at $6000 \mathrm{mg} / \mathrm{kg}$. The K:Na ratio correspondingly increased by a factor 11.7 (Fig. 1B). Bone Ca and P decreased to a lower level $(p<0.001)$ after cessation of supplemental feeding, with Ca probably yet unstabilised (Fig. 2). Bone ash correspondingly decreased from 712 to $600 \mathrm{~g} / \mathrm{kg}$ (Fig. 3). The Ca:P ratio was unaffected. 


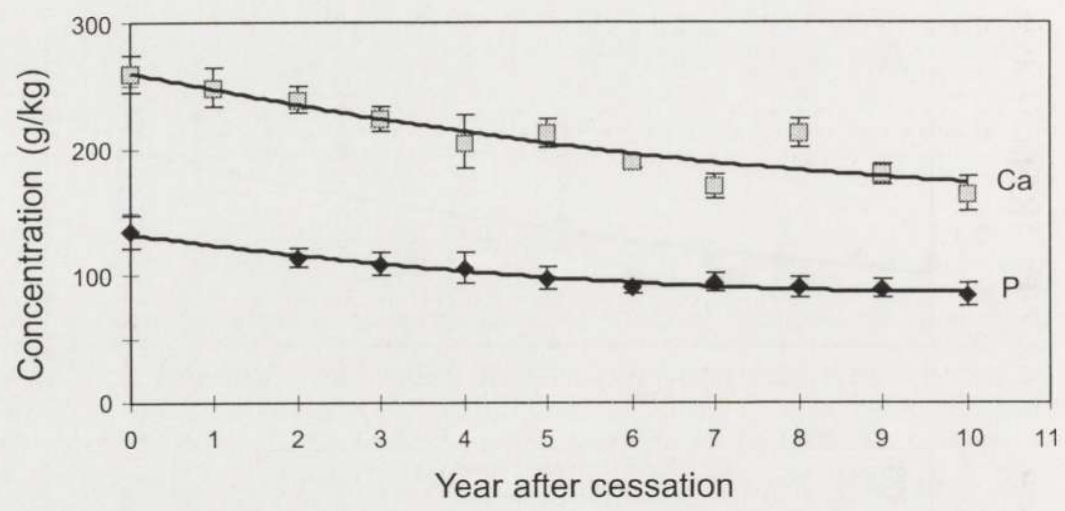

Fig. 2. $\mathrm{Ca}$ and $\mathrm{P}$ concentrations $(\mathrm{g} / \mathrm{kg} \pm \mathrm{SE})$ in red deer bone following cessation of supplemental feeding.

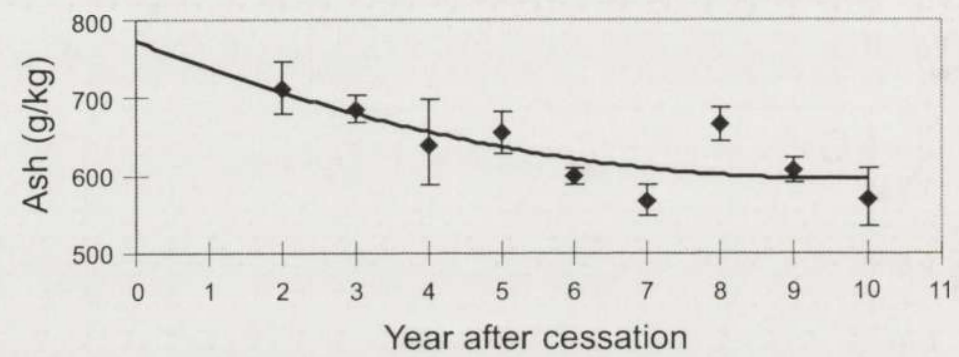

Fig. 3. Ash contents $(\mathrm{g} / \mathrm{kg} \pm \mathrm{SE})$ in red deer bone following cessation of supplemental feeding.

\section{Wild boar}

From an initial level of 139 , bone K increased $(p<0.001)$ to an apparently stable $5000 \mathrm{mg} / \mathrm{kg}$. Bone $\mathrm{Na}$ stabilised from an initial 2892 at approximately $6000 \mathrm{mg} / \mathrm{kg}$ and the K:Na ratio increased by a factor $40(p<0.001)$ (Fig. 1C). Bone Ca, P, Ca:P

Table $8 . \mathrm{Cu}, \mathrm{Fe}$, and $\mathrm{Zn}$ profiles $(\mathrm{mg} / \mathrm{kg} \mathrm{DM} \pm \mathrm{SE})$ in red deer and wild boar liver and kidney before and after cessation of supplemental feeding.

\begin{tabular}{|c|c|c|c|c|}
\hline & \multicolumn{2}{|c|}{ Initial value } & \multicolumn{2}{|c|}{ Range after cessation } \\
\hline & Red deer & Wild boar & Red deer & Wild boar \\
\hline Cu-liver & $83.2(1.2)$ & $19.1(1.1)$ & $65.0-135.0$ & $14.7-\quad 24.7$ \\
\hline Fe-liver & $432.7(1.1)$ & $569.6(1.3)$ & $329.3-486.4$ & $451.2-1144.8$ \\
\hline Zn-liver & $115.4(1.1)$ & $138.5(1.1)$ & $104.2-128.9$ & $97.1-163.2$ \\
\hline Cu-kidney & $21.1(1.1)$ & $23.4(1.1)$ & $18.2-29.0$ & $21.9-\quad 37.0$ \\
\hline Zn-kidney & $192.1(1.2)$ & $127.1(1.0)$ & $134.0-232.5$ & $121.4-135.4$ \\
\hline
\end{tabular}


ratio, and ash were not affected by cessation; ranges were 194-233, 92-98, 2.0-2.5 and $615-730 \mathrm{~g} / \mathrm{kg}$; current levels are $223.0( \pm 1.1), 96.4( \pm 1.1), 2.3( \pm 1.1)$ and $678.0( \pm 11.3) \mathrm{g} / \mathrm{kg}$ respectively.

In both species liver $\mathrm{Cu}, \mathrm{Fe}$, and $\mathrm{Zn}$, and kidney $\mathrm{Cu}$ and $\mathrm{Zn}$, were unaffected by cessation of supplemental feeding (Table 8).

\section{Discussion}

According to husbandry standards, red deer and wild boar would require approximately 5 and $8 \%$ CP in their food for maintenance (ARC 1981, Van Soest 1982, Robbins 1983). Even if requirements for growth were twice as high (Asleson et al. 1996), they would be sufficiently met by the quality of the natural diet. North-temperate ungulates accumulate body reserves during summer and adapt physiologically to the low nutritional plane, in terms of energy and protein, during winter (Belovsky 1986, Wilmshurst and Fryxell 1995, Parker et al. 1996). Our results indicate that during a poor mast winter, when energy contents of their diet dropped below $9 \mathrm{MJ} / \mathrm{kg} \mathrm{DM}$, wild boar would have to increase their ingestion by $30 \%$ to meet their energy demands, but, judging by the dry weights of their stomach contents, they did not. As a consequence, body reserves were completely depleted and recruitment the following spring was nil (Groot Bruinderink et al. 1994). The Veluwe obviously does not offer wild boar an alternative feeding for mast.

The red deer from this study would be in the danger zone of a $\mathrm{Ca}$ and $\mathrm{P}$ deficiency when we apply norm values for bone $\mathrm{Ca}$ and $\mathrm{P}$ in beef cattle, presented by Read et al. (1985). However, little is known about interspecific differences in nutrient metabolism (Fyffe 1996). Muir et al. (1987) in their experiments on red deer Ca metabolism, found a requirement of $5.2 \mathrm{~g} / \mathrm{d}$, which is low, compared to our $8.1 \mathrm{~g} / \mathrm{d}$. If we convert the estimated dietary P requirements of white-tailed deer, found by Grasman and Hellgren (1993), to the stag of our study, the requirement would be 2.8 instead of our calculated $3.8 \mathrm{~g} / \mathrm{d}$.

In the red deer from our study, as in many other herbivorous mammals, dietary $\mathrm{Na}$ is lowest in the growing season, and negative $\mathrm{Na}$ balances may be expected since most natural plant diets do not contain sufficient $\mathrm{Na}$ to provide for optimum performance (NRC 1980, Christian 1989). Ungulates are known to be able to adapt to low-sodium diets by reducing $\mathrm{Na}$ losses in urine, sweat, faeces and even saliva to very low levels. However, if threshold values of the homeostatic response are surpassed, the observed high $\mathrm{K}$ intake by red deer during the growing season, in combination with high water intake from the succulent vegetation, may cause excess Na losses through urine and faeces (Weeks and Kirkpatrick 1976, Staaland et al. 1980). We do not know whether red deer store $\mathrm{Na}$ in the saliva-rumen fluid system as shown by Belovsky and Jordan (1981) for moose, and whether bone $\mathrm{Na}$ should be considered as lost for maintaining $\mathrm{Na}$ balance, as suggested by Christian (1989). This would explain the rather stable bone $\mathrm{Na}$ and the unaffected Na profile in antlers that are to be wasted anyway. 
Mean dietary Na contents in the wild boar diet from our study can be considered inadequate, when compared to the level for growing pigs of $0.09 \%$ given by Alcantra et al. (1980).

We conclude therefore that red deer from our study are vulnerable to $\mathrm{Na}$ stress during the growing season, while wild boar may run the risk of a $\mathrm{Na}$ stress in particular during rich mast winters. Although mechanisms controlling body concentrations of $\mathrm{K}$ and $\mathrm{Na}$ are incompletely defined (NRC 1980), we argue that the observed gradual change in bone $\mathrm{K}: \mathrm{Na}$ ratio and bone $\mathrm{Na}$ profiles in both ungulate species, may be explained by the animals effort to maintain the balance of these electrolytes (osmolarity) and meanwhile achieve maximum $\mathrm{Na}$ retention in a $\mathrm{Na}$ poor environment (Black 1960, Meneely and Battarbee 1976). Samples from the selected forage types in the period before cessation were unavailable. Even if data would have been available, exclusion of $\mathrm{Na}$ uptake from supplied licks would have resulted in an underestimation of the total realised uptake (Table 9). Since a mixture of formerly applied supplemental forages (Table 9), even if ingested in small quantities, could have met the dietary $\mathrm{Ca}, \mathrm{P}$, and $\mathrm{Na}$ demands of both species, we suggest that the observed changes in mineral status are the result of a decreased mineral consumption, despite number reduction.

Nevertheless, our results on growth rate, body weight, age at first breeding, recruitment, and antler morphology, suggest sufficiently high dietary levels of energy (poor mast winters excluded in case of wild boar), protein, lipids, vitamins, and minerals (French et al. 1956, Ullrey et al. 1973, Mitchell and Crisp 1981, Leader-Williams and Ricketts 1982, Gilder and Boskey 1990, Leberg and Smith 1993).

In our study, rib bone was a better indicator for possible $\mathrm{Ca}$ and $\mathrm{P}$ shortages than antler material. This is in contrast to the idea that antlers react immediately to changes in the diet, in particular to malnutrition (Brown 1990). The explanation may be that during antlerogenesis, dietary $\mathrm{Ca}$ and $\mathrm{P}$ levels where in order $>4000$ and $>1800 \mathrm{mg} / \mathrm{kg}$ dry wt, while during the sampling period of rib bone, levels were $<4000$ and $<1500 \mathrm{mg} / \mathrm{kg}$ dry wt respectively. Reabsorption of minerals from the antler is impossible (Muir et al. 1987).

Further effects of decreased nutrient availability on mineral status of the animals depend on the size of the storage pool and may initially be masked by the

Table 9. $\mathrm{Ca}, \mathrm{P}$, and Na contents $(\mathrm{mg} / \mathrm{kg}$ DM) in the main supplemental forages (CVB 1991) and in the natural diets (this study) of red deer and wild boar (in rich + and poor - mast years).

\begin{tabular}{|c|c|c|c|c|c|c|c|c|}
\hline & \multicolumn{4}{|c|}{ Red deer } & \multicolumn{4}{|c|}{ Wild boar } \\
\hline & Pulp & Pellets & Lick & Natural & Maize & Pellets & Natural+ & Natural- \\
\hline $\mathrm{Ca}$ & 8500 & 30000 & 0 & 4100 & 400 & 13300 & 3700 & 3200 \\
\hline P & 900 & 3000 & 0 & 1600 & 3000 & 5700 & 1800 & 2200 \\
\hline $\mathrm{Na}$ & 1500 & 4000 & 38000 & 300 & 100 & 2300 & 600 & 800 \\
\hline
\end{tabular}


capacity of the body to maintain homeostasis (Langlands 1987). Depletion of the storage pool and subsequent depletion of the so-called functional pool, may only later lead to deficiencies, dysfunction's and disease (Suttle 1987). This may implicate a long delay in the development of most signs of deficiency (NRC 1988a). In this respect acidification of the environment may form an additional problem for herbivores inhabiting poor habitats in their quest for calcium (Graveland et al. 1994). Full understanding of $\mathrm{Na}, \mathrm{P}$, or Ca limitation in red deer and other herbivores requires further study, including experiments on physiological performance and more extensive integration of physiological and ecological studies. We argue that the latter should include further monitoring of the $\mathrm{Ca}, \mathrm{P}, \mathrm{K}$ and $\mathrm{Na}$ status of the animals of our study.

Acknowledgements: The work was supported by the Ministry of Agriculture, Nature Conservation and Fisheries (project Forest Grazing), the National Game Fund, the Royal Forestry 'Het Loo' and the State Forestry Service. Useful comments and suggestions, which improved an earlier version of the manuscript, were provided by R. J. Putman of the Manchester Metropolitan University, M. Verstegen of the Department of Animal Nutrition and B. Kemp of the Department of Animal Husbandry of Wageningen University, and our colleague A. T. Kuiters. We thank S. E. van Wieren of Wageningen University for data on digestibility.

\section{References}

Alcantra P. F., Hanson L. E. and Smith J. D. 1980. Sodium requirements, balance and tissue composition of growing pigs. Journal Animal Science 50: 1092-1101.

ARC Agricultural Research Council 1972. The Nutrient Requirements of Farm Livestock. No 2. Ruminants. Commonwealth Agricultural Bureaux, London: 1-286.

ARC Agricultural Research Council 1981. The Nutrient Requirements of Pigs. Commonwealth Agricultural Bureaux, London: 1-211.

Asleson M. A., Hellgren E. C. and Varner L. W. 1996. Nitrogen requirements for antler growth and maintenace in white-tailed deer. The Journal of Wildlife Management 60: 744-752.

Belovsky G. E. 1986. Optimal foraging and community structure: implications for a guild of generalist grassland herbivores. Oecologia 70: 35-52.

Belovsky G. E. and Jordan P. A. 1981. Sodium dynamics and adaptations of a moose population. Journal of Mammalogy 62: 613-621.

Black D. A. K. 1960. Current concepts of potassium metabolism. Journal of Pediatrics 56: 814-825.

Bokdam J. and Wallis de Vries M. F. 1992. Forage quality as a limiting factor for cattle grazing in isolated Dutch nature reserves. Conservation Biology 6: 399-408.

Brown R. D. 1990. Nutrition and antler development. [In: Horns, pronghorns and antlers. G. A. Bubenik and A. B. Bubenik, eds]. Springer Verlag, New York: 426-441.

Christian D. P. 1989. Effects of dietary sodium and potassium on mineral balance in captive meadow voles (Microtus pennsylvanicus). Canadian Journal of Zoology 67: 168-177.

CVB 1991. [Catlle-feeding table: data on chemical composition, digestibility and nutritive value of forages]. Centraal Veevoederbureau Lelystad, The Netherlands: 1-167. [In Dutch]

Fennessy P. F., Moore G. H. and Corson I. D. 1981. Energy requirements of red deer. Proceedings New Zealand Society of Animal Production 41: 167-173.

French C. E., McEwen L. C., Magruder N. D., Ingram R. H. and Swift R. W. 1956. Nutrient requirements for growth and antler development in the white-tailed deer. The Journal of Wildlife Management 20: 221-232.

Fyffe J. J. 1996. Serum copper concentrations and clinical signs in red deer (Cervus elaphus) during drought in central Virginia. Australian Veterinary Journal 73: 188-191. 
Genstat 5 Committee 1993. Genstat 5 Reference Manual. Clarendon Press, Oxford: 1-749.

Gilder H. and Boskey A. L. 1990. Dietary lipids and the calcifying tissues. [In: Nutrition and bone development. D. J. Simmons J. B. Hacker and J. H. Ternouth, eds]. Oxford University Press, Oxford: 244-265.

Grasman B. T. and Hellgren E. C. 1993. Phosphorus nutrition in white-tailed deer: nutrient balance, physiological responses, and antler growth. Ecology 74: 2279-2296.

Graveland J., van der Wal R., van Balen J. H. and van Noordwijk A. J. 1994. Poor reproduction in forest passerines from decline of snail abundance on acidified soils. Nature 368: 446-448.

Groot Bruinderink G. W. T. A., Hazebroek E. and van der Voet H. 1994. Diet and condition of wild boar, Sus scrofa scrofa, without supplementary feeding. Journal of Zoology, London 233: 631-648.

Groot Bruinderink G. W. T. A. and Hazebroek E. 1995. Ingestion and diet composition of red deer (Cervus elaphus L.) in the Netherlands from 1954 till 1992. Mammalia 59: 187-195.

Hyvärinen H., Kay R. N. and Hamilton W. J. 1977. Variations in weight, specific gravity and composition of the antlers of red deer (Cervus elaphus L.). British Journal of Nutrition 38: 301-312.

Hyvärinen H. and Nygrén T. 1993. Accumulation of copper in the liver of moose in Finland. Journal of Wildlife Management 57: 469-474.

Jongbloed A. W. 1987. [Phosphorus in the feeding of pigs]. Ph D thesis, Agricultural University, Wageningen: 1-191. [In Dutch]

INRA 1984. L'alimentation des animaux monogastriques: porc, lapin, volailles. INRA, Paris.

Langlands J.P. 1987. Assessing the nutrient status of herbivores. [In: The Nutrition of Herbivores. J. B. Hacker and J. H. Ternouth, eds]. Academic Press, Sydney, Australia: 363-390.

Leader-Williams N. and Ricketts C. 1982. Growth and condition of three introduced reindeer herds on South Georgia: the effects of diet and density. Holarctic Ecology 5: 381-388.

Leberg P. L. and Smith M. H. 1993. Influence of density on growth of white-tailed deer. Journal of Mammalogy 74: 723-731.

Lincoln G. A. 1992. Biology of antlers. Journal of Zoology, London 226: 517-528.

Little D. A. 1980. Observations on the phosphorus requirements of cattle for growth. Research Veterinary Science 28: 258-260.

Ma W., van Wezel H. and van den Ham D. 1992. [Backgroundlevels of 15 metals in soil, vegetation and fauna in 12 nature reserves in the Netherlands]. RIN-rapport 92/11. [In Dutch]

McCullagh P. and Nelder J. A. 1989. Generalized linear models. 2nd ed. Chapman and Hall, London: 1-346.

McDowell L. R., Conrad J. H. and Ellis G. 1984. Mineral deficiencies and imbalances, and their diagnosis. [In: Herbivore nutrition in the subtropics and tropics. F. M. C. Gilchrist and R. I. Mackie, eds]. The Science Press, Craighall: 67-88.

McNaughton S. J. 1990. Mineral nutrition and seasonal movements of African migratory ungulates. Nature 345: 613-615.

Meneely G. R. and Battarbee H. D. 1976. Sodium and potassium. Nutrition Reviews 34: 225-235.

Mitchell B. and Crisp J. M. 1981. Some properties of red deer (Cervus elaphus) at exceptionally high population-density in Scotland. Journal of Zoology, London 193: 157-169.

Muir P. D., Sykes A. R. and Barrell G. K. 1987. Calcium metabolism in red deer (Cervus elaphus) offered herbages during antlerogenesis: kinetic and stable balance studies. Journal of Agricultural Science 109: 357-364.

NEN 1964. [Standards for Chemical Analysis. Assessment of N according to Kjeldahl, NEN 3106-12]. Nederlands Normalisatie Instituut, Delft: 1-56. [In Dutch]

NEN 1981. [Standards for Chemical Analysis. Fleischman destruction technique, NEN 6464]. Nederlands Normalisatie Instituut, Delft: 1-35. [In Dutch]

NEN 1986. [Standards for Chemical Analysis. Microwave destruction techniques, NEN 6439]. Nederlands Normalisatie Instituut, Delft: 1-34. [In Dutch]

NRC National Research Council 1980. Mineral tolerance of domestic animals. National Academy of Sciences, Washington D.C.: 1-111. 
NRC National Research Council 1988a. Subcommittee on dairy cattle nutrition. Nutrient requirements of dairy cattle. Sixth revised edition. National Academy Press, Washington: 1-80.

NRC National Research Council 1988b. Subcommittee on swine nutrition. Nutrient requirements of swine. Ninth revised edition. National Academy Press, Washington: 1-90.

Parker K. L., Gillingham M. P., Hanley T. A. and Robbins C. T. 1996. Foraging efficiency: energy expenditure versus energy gain in free ranging black-tailed deer. Canadian Journal of Zoology 74: $442-450$.

Pepin D. and Mauget R. 1989. The effect of planes of nutrition on growth and attainment of puberty in female wild boars raised in captivity. Animal Reproductive Science 20: 71-77.

Putman R. J., Langbein J., Hewison A. J. M. and Sharma S. K. 1996. Relative roles of density-dependent and density-independent factors in population dynamics of British deer. Mammal Reviews 26: 81-101.

Read M. V. P. , Engels E. A. N. and Smith W. A. 1985. Phosphorus and the grazing ruminant. 3. Rib bone samples as an indicator of the P status of cattle. South African Journal of Animal Science 16: $13-17$.

Robbins C. T. 1983. Wildlife feeding and nutrition. Academic Press, Inc., New York: 1-378.

Staaland H., White R. G., Luick J. R. and Holleman D. F. 1980. Dietary influences on sodium and potassium metabolism of reindeer. Canadian Journal of Zoology 58: 1728-1734

Suttle N. F. 1987. The absorption, retention and function of minor nutrients. [In: The Nutrition of Herbivores. J. B. Hacker and J. H. Ternouth, eds]. Academic Press, Sydney: 333-361.

Ullrey D. E., Youatt W. G., Johnson H. E., Fay L. D., Schoepke B. L., Magee W. T. and Keahey K. K. 1973. Calcium requirements of weaned white-tailed deer fawns. The Journal of Wildlife Management 37: $187-194$.

Van Es A. J. H. 1978. Feed evaluation for ruminants: 1. The systems in use from May 1977 onwards in the Netherlands. Livestock Production Science 5: 331-345.

Van Soest P. J . 1982. Nutritional ecology of the ruminant. O\&B Books, Corvallis, Oregon: 1-000.

Van Wieren S. E. 1996. Digestive strategies in ruminants and nonruminants. Ph D thesis, Agricultural University, Wageningen: 1-191.

Wallis de Vries M. F. 1994. Foraging in a landscape mosaic. Ph D thesis, Agricultural University, Wageningen: $1-161$.

Weeks H. P. and Kirkpatrick C. M. 1976. Adaptations of white-tailed deer to naturally occurring sodium deficiencies. The Journal of Wildlife Management 40: 610-625.

Wilmshurst J. F. and Fryxell J. M. 1995. Patch selection by red deer in relation to energy and protein intake: a re-evaluation of Langvatn and Hanley's (1993) results. Oecologia 104: 297-300.

Received 10 September 1998, accepted 15 April 1999. 